\title{
Bilateral Bifid Mandibular Condyle: A Case Report
}

\author{
Proceso Condilar Bífido Bilateral: Reporte de Caso \\ "Suzana Lubambo de Melo; ${ }^{* *}$ Joanna Martins Novais Barbosa; ${ }^{* * *}$ Aline Carvalho Peixoto; \\ *****Thiago de Santana Santos \& *Marleny Gerbi
}

MElO, S. L.; BARBOSA, J. M. N.; PEIXOTO,A. C.; SANTOS, T. S. \& GERBI, M. Bilateral bifid mandibular condyle: a case report. Int. J. Morphol., 29(3):922-926, 2011.

SUMMARY: The bifid mandibular condyle is an exceedingly rare anomaly, frequently diagnosed as an incidental finding in a panoramic radiograph. Its etiology and pathogenesis are unknown, though the most acceptable theory suggests that trauma is at the origin of the condition. This article reports a new case of bilateral bifid condyle in a 21-year-old female with history of trauma in childhood.

KEY WORDS: Condylar process; Mandibular condyle; Anatomic variation; Computed tomography.

\section{INTRODUCTION}

The bifid mandibular condyle (BMC), a condition in which the head of the condyle is duplicated or lobulated, is exceptionally rare. BMC was first reported by Hrdlicka (1941) who analyzed 21 dried specimens from a collection belonging to the Smithsonian Institution in Washington DC.

Bifidism can be associated with a variety of symptoms, which are however, absent in most instances. It is frequently discovered in routine radiographic examination or during the investigation of other problems (McCormick et al., 1989; Artvinli \& Kansu, 2003; Antoniades et al., 2004; Açikgöz, 2006). Its etiology and pathogenesis are uncertain, but the most tenable theory is that it is of traumatic origin (Thomason \& Yusuf, 1986; Artvinli \& Kansu).

In recent years, there has been a sudden increase in the number of cases reported, which may be attributed to the widespread use of radiographic methods (Heserk et al., 2004).

The purpose of this article is to report a case of bilateral bifid condyle with possible traumatic etiology and to review the relevant literature.

\section{CASE REPORT}

A 21-year-old female patient reported to a private clinic with complaints of pain and clicking in the temporomandibular joints (TMJ) as well as frequent headaches. She reported that she had felt TMJ discomfort for the past 6 years and that the headaches had become more frequent over the last months, though there was no complaint of mouth opening limitation. Her medical history was noncontributory except for a skating accident at the age of 12 years, with laceration of the soft tissue of the chin. On clinical examination, there was no detectable facial asymmetry.

A panoramic radiograph showed a discrete modification of both mandibular condyles suggestive of bifid formation (Fig. 1). In order to better evaluate the morphology of the TMJ in sagittal and coronal view, further investigation with cone beam computed tomography was obtained, and confirmed the markedly deformed appearance of the condyles. Both condyles had two distinct heads, despite the glenoid fossa and the articular eminence were conserved. The joint head orientation was in the mediolateral direction. Three-dimensional reconstructions were also performed and clearly revealed a notch on the articulating surface of the condyles (Figs. 2, 3 and 4). 


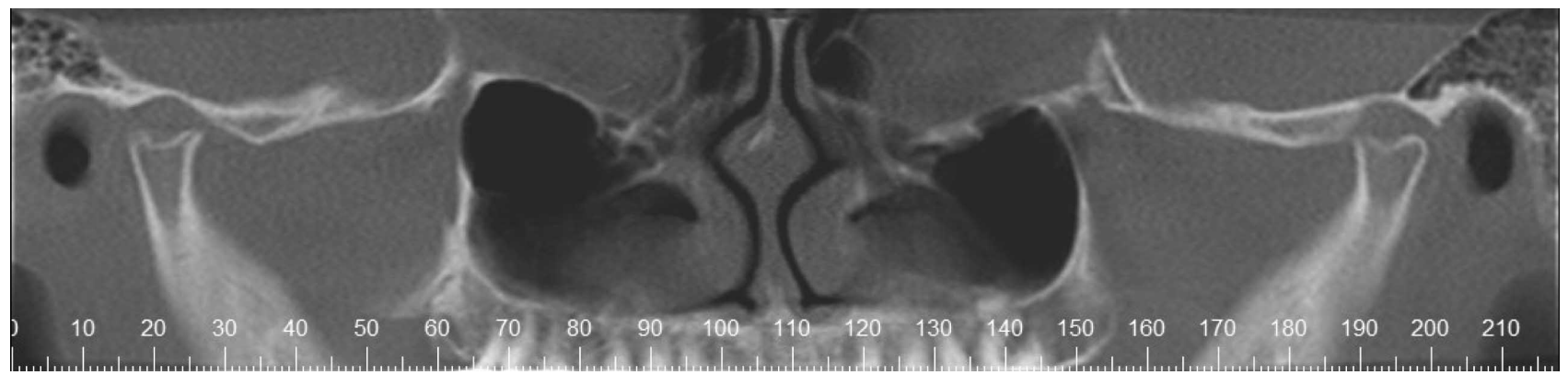

Fig. 1. Panoramic view of cone beam computed tomography showing bilateral bifid condyle.
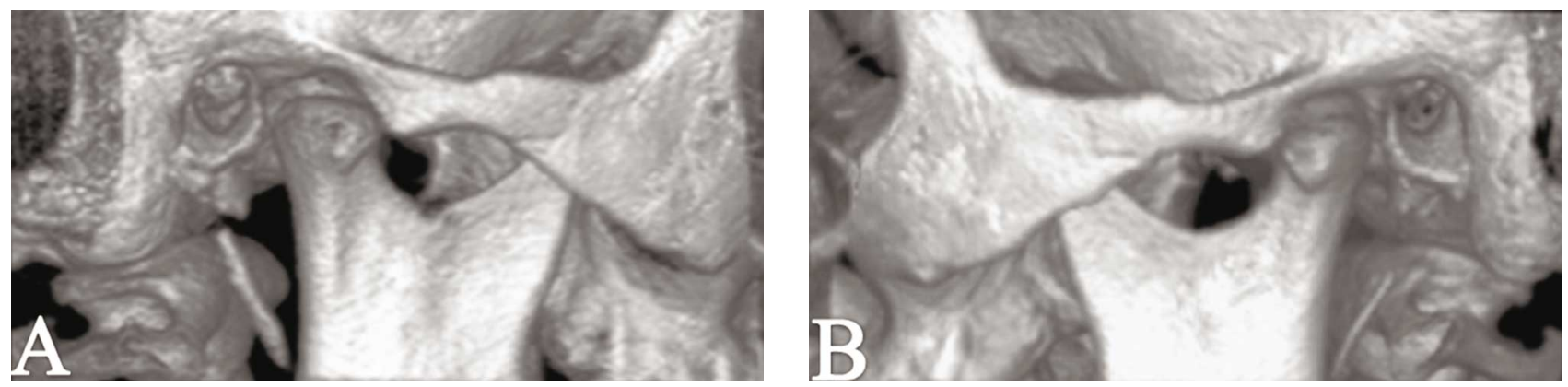

Fig. 2. Tridimensional images from TMJ with closed mouth in lateral view. A. Right; B. Left.

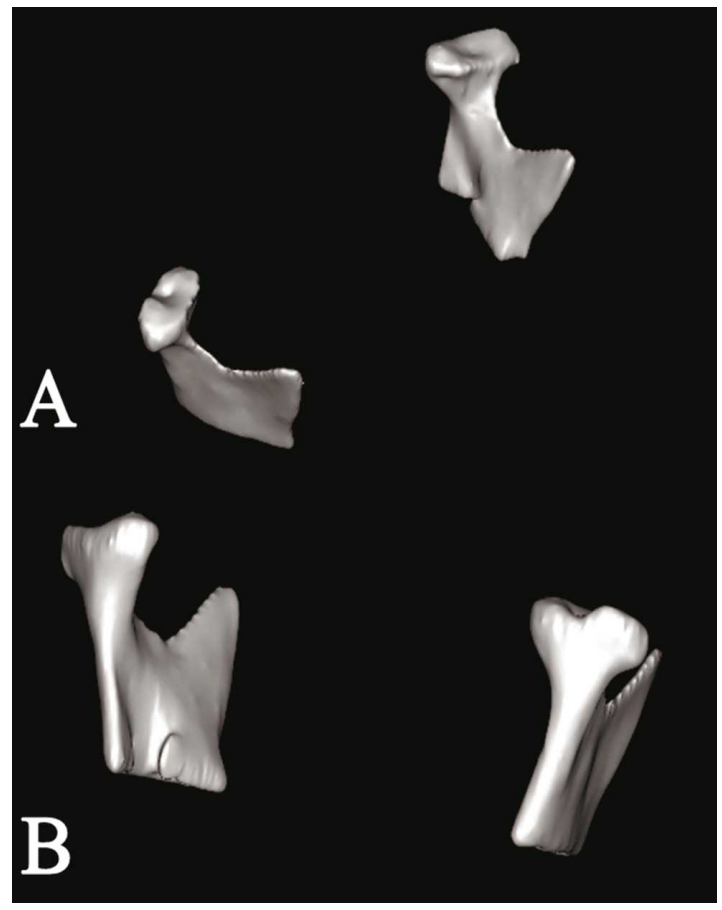

Fig. 3. Tridimensional images from TMJ. A. Superior view; B. Posterior view.

\section{DISCUSSION}

According to the literature at least 50 cases of bifid mandibular condyles and 2 cases of trifid condyles (Artvinli

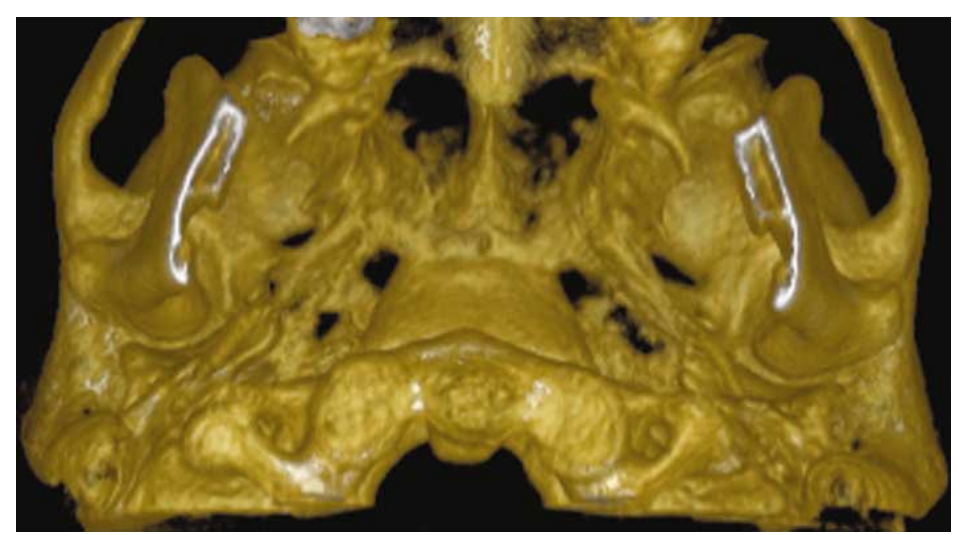

Fig. 4. Tridimensional images from TMJ with closed mouth in inferior view.

\& Kansu; Antoniades et al.) in living patients have been reported so far. This number has suddenly increased probably as a result of improved imaging techniques. In spite of this, the disorder is still considered rare (Tunçbilek et al., 2006).

The etiology and pathogenesis of bifid condyle are uncertain; however, there are several postulates about it. It is said that it may be a dysplasic process produced by some alteration of the cartilage during development (Martín et al., 2005). Poswillo (1972) studied the effects of condylectomy in monkeys and reported that some alterations in the position of the fibroblastic cells surrouding the disc surface could influence the process of bone remodeling, causing the development of bifid condyle. 
Persistence of fibrovascular septae in the developing condylar head has been suggested as the cause of bifid condyle. Normally, these septae are present in the condylar cartilage at around 20 weeks of fetal development. After examining 12 human TMJ aged between 20 weeks of fetal life to 19 months, Blackwood (1957) suggested that the permanence of the septae after the second year of life could be the cause of impaired ossification.

While conducting experiments in rats, Gunlach et al. (1987) found 3 cases of bifid condyles in offsprings of pregnant rats that had been given teratogenic substances. Other suggestions are that infection, irradiation, nutritional disorders, genetic, endocrinological or pharmacological factors could be the cause of the condition.

Other authors proposed that trauma involving TMJ or micro trauma due to malocclusion might cause bifid condyle (Artvinli \& Kansu; Heserk et al.; de Sales et al., 2004; Fuentes et al., 2009). Thomason \& Yusuf reported 2 cases related to condyle fracture post-trauma, which, after healing, eventually led to bifid condyle formation. Standnicki (1971) reported a case of a 3-year-old-girl with limited mouth opening and a bifid condyle following forceps delivery.

The orientation of bifid condyle has been classified as anterior-posterior and mediolateral. Szentpetery et al. (1990) examined 2077 condyles of prehistoric and historic skulls, 7 cases showing sings of bifidity, observed that when 2 parts of the condylar lay in the sagittal plane, trauma was believed to be the cause of the condition, whereas when they lay in the coronal plate, the persistence of the fibrous septa was the possible cause. While this may be true for the majority of cases, some mediolateral bifid condyles have been reported following sagittal fracture through the condylar head and condylar neck fracture (Daniels \& Ali, 2005).

The BMC does not appear to have a predilection for any particular race, age or gender (Loh \& Yeo, 1990; Antoniades et al.). Most of the patients with known age are over 20 years old (Heserk et al.). Although BMC is observed uni- and bilaterally, it has been reported that unilateral bifid mandibular condyle is 2.5 times more frequent than the bilateral form, and the left condyle is 1.5 times more often affected than the right condyle. Shaber (1987) described the first case of bilateral bifid condyles in a living patient. Since then, 13 additional cases have been reported (McCormick et al.; Stefanou et al., 1998; Artvinli \& Kansu; Antoniades et al.; Açikgöz; Sales et al., 2007; Gunduz et al., 2010).

According to Loh \& Yeo, $67 \%$ of the patients with BMC were asymptomatic, the condition was detected as an incidental finding during dental radiographic examination.
Nonetheless, it can be associated with a variety of symptoms such as pain (McCormick et al.), restriction of mandibular movement (Martín et al.), trismus (Antoniades et al.), swelling (Tunçbilek et al.), ankylosis (Daniels \& Ali; Sales et al.), and facial asymmetries (Thomason \& Yusuf). The most common and predominant symptoms are by far, TMJ sounds (McCormick et al.; Stefanou et al.; Heserk et al.). It has been suggested that arthritic changes might be seen in most bifid condyle cases and also that ostreoarthrosis might develop in cases resulting from trauma (Hrdlicka). However, there is not sufficient data to evaluate the long term effects and complications of bifid condyle especially in relation to TMJ function (Açikgöz).

The treatment of the symptomatic bifid condyle associated with limited mouth opening and ankylosis requires surgical intervention (Artvinli \& Kansu; de Sales et al.). There are three basic techniques for surgical correction of temporomandibular ankylosis: gap arthroplasty, interpositional arthroplasty and joint reconstruction (Daniels $\&$ Ali). In the asymptomatic cases, the treatment is usually conservative and similar to the treatment for the closely associated TMJ pain dysfunction syndrome (analgesics and anti-inflammatory agents, muscle relaxants, physiotherapy, splint) (Antoniades et al.; Martín et al.), and so the patients must be controlled and followed-up.

The progress of diagnostic imaging has included the development and improvement of new imaging techniques that allow easier and earlier detection of pathological changes, which, otherwise, could be extremely hazardous to the patient. In this field, advances in radiographic modalities and imaging methods have led to various options for visualizing TMJ.

Although panoramic radiograph is a valid diagnostic tool for the diagnosis of $\mathrm{BMC}$, conventional radiographs are not sufficient to reach a final diagnosis (Artvinli \& Kansu). Detailed evaluation of the condylar morphology is also necessary in order to differentiate BMC from other degenerative lesions such as tumors, cysts, metastatic or metabolic lesions. Computed tomography (CT) is the best choice for the osseous pathologies of the temporomandibular joint because it allows bilateral visualization without superimposition (Tunçbilek et al.).

Three-dimensional CT reconstructed images enable the radiologist to visualize the condyle and its relationship with the base of the skull and surrounding structures, as well as to manipulate the image data quickly (Stefanou et al.).

Besides using CT scan, Açikgöz employed openclosed lateral radiography of the TMJ. In addition, the author 
suggested that the magnetic resonance imaging (MRI) is necessary to evaluate the internal derangement of the TMJ and joint disk.

In the present case, the patient recalled a trauma to the chin in childhood which could have affected the TMJ. Whether there was a condyle fracture or not is unknown. Thus, these bifid mandibular condyles may have resulted from the condylar remodeling following trauma. Even though there is no image record previous to that time to assure the association, this account cannot be disregarded. The patient complaints were TMJ sounds, pain and headaches, and the treatment proposed was medication and control. The use of CT scan showed to be more advantageous than other imaging methods.

Despite the absence of clinical symptomatology in the majority of the cases, the radiologist must be aware of this abnormality and of its implication in functional and morphological changes.

MELO, S. L.; BARBOSA, J. M. N.; PEIXOTO,A. C.; SANTOS, T. S. \& GERBI, M. Proceso condilar bífido bilateral: reporte de caso. Int. J. Morphol., 29(3):922-926, 2011.

RESUMEN: El proceso condilar bífido es una anomalía muy rara. Se diagnostica como un hallazgo accidental en una radiografía panorámica. Su etiología y patogenia son desconocidas, aunque la teoría más aceptada sugiere que el trauma está en el origen de esta condición. Este artículo presenta un nuevo caso de proceso condilar bífido bilateral en una mujer de 21 años de edad con antecedentes de trauma en la infancia.

PALABRAS CLAVE: Proceso condilar; Cóndilo mandibular; Variación anatómica; Tomografía computarizada.

\section{REFERENCES}

Açikgöz, A. Bilateral bifid mandibular condyle: a case report. J. Oral Rehabil., 33(10):784-7, 2006.

Antoniades, K.; Hadjipetrou, L.; Antoniades, V. \& Paraskevopoulos, K. Bilateral bifid condyle. Oral Surg. Oral Med. Oral Pathol. Oral Radiol. Endod., 97(4):535-8, 2004.

Artvinli, L. B. \& Kansu, O. Trifid mandibular condyle: A case report. Oral Surg. Oral Med. Oral Pathol. Oral Radiol. Endod., 95(2):251-4, 2003.

Blackwood, H. J. The double-headed mandibular condyle. Am. J. Phys. Anthropol., 15(1):1-8, 1957.

Daniels, J. S. \& Ali, I. Post-traumatic bifid condyle associated with temporomandibular joint ankylosis: Report of a case and review of the literature. Oral Surg. Oral Med. Oral Pathol. Oral Radiol. Endod., 99(6):682-8, 2005.

de Sales, M. A.; do Amaral, J. I.; de Amorim, R. F. \& Almeida Freitas, R. Bifid Mandibular Condyle: Case Report and Etiological Consideratons. J. Can. Dent. Assoc., 70(3):158-62, 2004.

Fuentes, F. R.; Flores, H. F.; Mella, H. S. \& Lillo, T. F. Bifid Condylar Process: Cases Report. Int. J. Morphol., 27(2):539-41, 2009.
Gunduz, K.; Avsever, H. \& Karacayli, U. Bilateral Bifid Condylar Process. Int. J. Morphol., 28(3):941-4, 2010.

Gunlach, K. K.; Furhmann, A. \& Beckmann-Van der Ven, G. The double-headed mandibular condyle. Oral Surg. Oral Med. Oral Pathol. Oral Radiol. Endod., 64(2):249-53, 1987.

Heserk, N.; Özbek, M.; Tas sar, F.; Akpinar, E. \& Firat, M. Bifid mandibular condyle: a case report. Dent. Traumatol., 20(3):184-6, 2004.

Hrdlicka, A. Lower jaw: double condyles. Am. J. Phys. Anthropol., 28:75-89, 1941.

Loh, F. C. \& Yeo, J. F. Bifid mandibular condyle. Oral Surg. Oral Med. Oral Pathol., 69(1):24-7, 1990.

Martín, G. C.; Terán, T. G.; Reija, M. F. G.; Santolino, S. S.; Bustillo, R. S. Cóndilo bífido: A propósito de un caso. Med. Oral Patol. Oral Cir. Bucal, 10:277-9, 2005.

McCormick, S. U.; McCormick, S. A.; Graves, R. W. \& Pifer, R. G. Bilateral bifid mandibular condyles. Report of three cases. Oral Surg. Oral Med. Oral Pathol., 68(5):555-7, 1989.

Poswillo, D. E. The late effects of mandibular 
MELO, S. L.; BARBOSA, J. M. N.; PEIXOTO,A. C.; SANTOS, T. S. \& GERBI, M. Bilateral bifid mandibular condyle: a case report. Int. J. Morphol., 29(3):922-926, 2011.

condylectomy. Oral Surg. Oral Med. Oral Pathol. Oral Radiol. Endod., 33(4):500-12, 1972.

Sales, M. A.; Oliveira, J. X. \& Cavalcanti, M. G. Computed tomography imaging findings of simultaneous bifid mandibular condyle and temporomandibular joint ankylosis: case report. Braz. Dent. J., 18(1):74-7, 2007.

Shaber, E. P. Bilateral bifid mandibular condyles. Cranio, 5(2):191-5, 1987.

Stadnicki, G. Congenital double condyle of the mandible causing temporomandibular joint ankylosis. J. Oral Surg., 29(3):208-11, 1971.

Stefanou, E. P.; Fanourakis, I. G.; Vlastos, K. \& Katerelou, J. Bilateral bifid mandibular condyles. Report of four cases. Dentomaxillofac. Radiol., 27(3):186-8, 1998.

Szentpetery, A.; Kocsis, G. \& Marcsik, A. The problem of the bifid mandibular condyle. J. Oral Maxillofac. Surg., 48(12):1254-7, 1990.

Thomason, J. M. \& Yusuf, H. Traumatically induced bifid mandibular condyle: report of two cases. Br. Dent. J., 161(8):291-3, 1986.

Tunçbilek, G.; Cavdar, G. \& Mavili, M. E. Bifid mandibular condyle: a rare disorder. J. Craniofac. Surg., 17(6):1207$9,2006$.
Correspondence to:

Thiago de Santana Santos

University of Pernambuco

Faculdade de Odontologia de Pernambuco (FOP/UPE)

Avenida General Newton Cavalcanti, 1650

Tabatinga - Camarabige

Pernambuco

CEP: 54753220

BRAZIL

Phone: +558131847652

Fax: +558131847686

Email: thiago.ctbmf@yahoo.com.br

Received: 30-03-2011

Accepted: 27-06-2011 